\title{
Assessment of historical changes (1959-2012) and the causes of recent break-ups of the Petersen ice shelf, Nunavut, Canada
}

\author{
Adrienne WHITE, ${ }^{1}$ Luke COPLAND, ${ }^{1}$ Derek MUELLER, ${ }^{2}$ Wesley VAN WYCHEN ${ }^{1}$ \\ ${ }^{1}$ Department of Geography, University of Ottawa, Ottawa, Ontario, Canada \\ E-mail: awhit059@uottawa.ca \\ ${ }^{2}$ Geography and Environmental Studies, Carleton University, Ottawa, Ontario, Canada
}

\begin{abstract}
Aerial photography and satellite imagery of the Petersen ice shelf, Nunavut, Canada, from 1959 to 2012 show that it was stable until June 2005, after which a series of major calving events in the summers of 2005, 2008, 2011 and 2012 resulted in the loss of $\sim 61 \%$ of the June 2005 ice-shelf area. This recent series of calving events was initiated by the loss of extensive regions of $>50$-year-old multiyear landfast sea ice from the front of the ice shelf in summer 2005. Each subsequent calving event has been preceded by open-water conditions and resulting loss of pack-ice pressure across the front of the ice shelf, and most occurred during record warm summers. Ground-penetrating radar (GPR) ice thickness measurements and RADARSAT-2 derived observations of surface motion indicate that tributary glaciers provided total ice input of $1.19-5.65 \mathrm{Mt} \mathrm{a}^{-1}$ to the ice shelf from 2011 to 2012 , far below the mean surface loss rate of $28.45 \mathrm{Mt} \mathrm{a}^{-1}$. With recent losses due to calving and little evidence for current basal freeze-on, this suggests that the Petersen ice shelf will no longer exist by the 2040s, or sooner if further major calving events occur.
\end{abstract}

KEYWORDS: Arctic glaciology, ice shelves, ice velocity, ice-shelf break-up, ice-shelf tributary glaciers

\section{INTRODUCTION}

Arctic ice shelves are typically defined as thick $(>20 \mathrm{~m})$ masses of floating ice that are attached to the coast, and are characterized by an undulating surface of ridges and troughs produced from winds and accentuated via meltwater ponds (Hattersley-Smith, 1957; Dowdeswell and Jeffries, in press). They form from glacier input and/or accretion of multi-year sea ice (MYI), and can continue to gain mass by accumulation of snowfall and/or basal freeze-on (Dowdeswell and Jeffries, in press).

The recent break-up of ice shelves along the northern coast of Ellesmere Island, Nunavut, Canada, has been linked to climate warming and to the loss of multi-year landfast sea ice (MLSI) (Copland and others, 2007). These changes are of particular concern for the stability of the remaining Petersen ice shelf, yet no prior studies regarding the dynamics, physical characteristics or historical changes of this ice mass exist. This limits the ability to understand how and why the ice shelf is changing, and to predict how it will react to current and future climate forcing. This paper provides the first comprehensive survey of the Petersen ice shelf by quantifying historical changes in its areal extent (from the 1950s to 2012), and determining its current ice thickness, surface motion and mass balance. The results enable predictions about the future stability of the ice shelf and provide a baseline against which future monitoring studies can be compared. An assessment of the patterns of recent climate changes in this region is also undertaken to aid in determining the conditions favourable for ice-shelf calving.

\section{BACKGROUND}

Ice shelves began to form along the northern coast of Ellesmere Island 4000-5500 years ago (England and others, 2008; Antoniades and others, 2011). Expeditions by
P. Aldrich and R. Peary at the turn of the 20th century provide the first observations of a continuous feature, which, at that time, extended along the entire coast of northern Ellesmere Island with an area of $\sim 8900 \mathrm{~km}^{2}$ (Vincent and others, 2001). Prior to the 1950s the 'Ellesmere ice shelf' was reduced to several individual ice shelves (Koenig and others, 1952; Jeffries, 1987). During the 1960s there were several large calving events, particularly from the Ward Hunt Ice Shelf (which lost $596 \mathrm{~km}^{2}$ between 1961 and 1962), but for the remainder of the 20th century there was generally little change observed (Jeffries, 1982; Jeffries and Serson, 1983; Mueller and others, 2003).

By the start of the 21st century six ice shelves remained, namely the Ward Hunt, Markham, Ayles, Serson, Milne and Petersen ice shelves, with a total area of $\sim 1043 \mathrm{~km}^{2}$ (Mueller and others, 2006). There was one calving event ( $6 \mathrm{~km}^{2}$ loss) between 2000 and 2002 at the Ward Hunt Ice Shelf, which was also associated with widespread fracturing and the drainage of a floating layer of fresh water (epishelf lake) from the landward side of the ice shelf (Mueller and others, 2003). By August 2005 large-scale collapses occurred, resulting in the complete loss of the Ayles ice shelf $\left(87 \mathrm{~km}^{2}\right)$ and a calving event at the Petersen ice shelf $\left(12.6 \mathrm{~km}^{2}\right.$ ) (Copland and others, 2007). The summer of 2008 was a particularly active summer, with calving at the Ward Hunt $\left(42 \mathrm{~km}^{2}\right)$ and the Serson $\left(122 \mathrm{~km}^{2}\right)$ and the complete loss of the Markham ice shelf $\left(50 \mathrm{~km}^{2}\right.$ ) (Mueller and others, 2008). The last major calving event of the Ellesmere ice shelves occurred during summer 2011, when the last $32 \mathrm{~km}^{2}$ of the Serson was lost, and the Ward Hunt Ice Shelf fractured into two and lost $39 \mathrm{~km}^{2}$. This resulted in a total area of the Ellesmere ice shelves of $563 \mathrm{~km}^{2}$ by the end of 2011, 54\% of the total area in 2005 (Kealey and others, 2011).

Here we use the term 'break-up' to refer to in situ fracturing, and 'calving' to refer to the production of icebergs and ice islands that occur after break-up when 


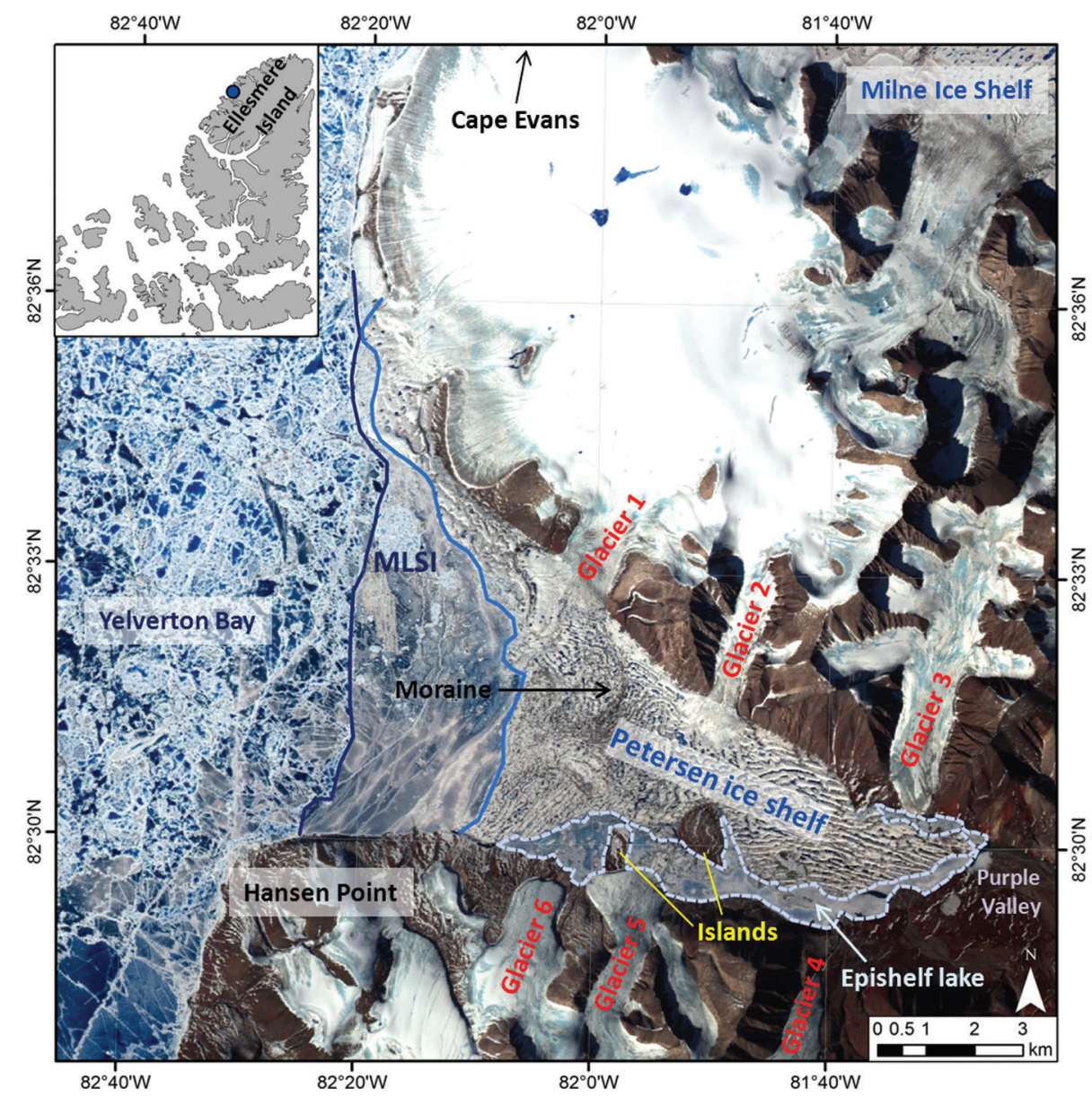

Fig. 1. Study area map of Petersen Bay overlaid on an Advanced Spaceborne Thermal Emission and Reflection Radiometer (ASTER) L1B satellite scene from 16 July 2009. Inset: blue dot indicates the location of the Petersen ice shelf along the northern coast of Ellesmere Island.

open water is present. These events typically produce ice islands, which are defined as large floating, tabular icebergs with an undulating surface, that have thicknesses ranging from 30 to $50 \mathrm{~m}$, and surface areas ranging from a few thousand square metres to hundreds of square kilometres (Jeffries, 1992; CIS, 2005). To be considered an ice island, the minimum amount of ice protruding above sea level must be $2 \mathrm{~m}$ (Jeffries, 1992) or $5 \mathrm{~m}$ (CIS, 2005), depending on the definition used.

\section{STUDY SITE}

The Petersen ice shelf (unofficial name; $82^{\circ} 31^{\prime} \mathrm{N}, 81^{\circ} 45^{\prime} \mathrm{W}$ ) is located on the northern coast of Ellesmere Island and occupies Petersen Bay, which opens westwards into Yelverton Bay (Fig. 1). The study site includes the ice shelf, a fringe of MLSI on the west side of the ice shelf, two tributary glaciers (Glaciers 1 and 2) and the remaining ice cover of Petersen Bay. In this study the front of the ice shelf is considered to be the area that opens into Yelverton Bay, and the back is considered to be the eastern edge at the head of Petersen Bay. The ice shelf was up to $17 \mathrm{~km}$ long and $12 \mathrm{~km}$ wide in 2000, with an area of $\sim 51.2 \mathrm{~km}^{2}$ (Mueller and others, 2006). The surface of the Petersen ice shelf is characterized by elongated troughs and ridges, with mixed orientations at the front and a northwest/southeast orientation at the back. There appear to be curved moraines towards the front of the ice shelf, likely deposited by tributary glaciers (Fig. 1). Six glaciers flow towards Petersen Bay: three along the northern edge and three along the southern edge (Fig. 1). However, only two of these glaciers are currently connected to the ice shelf, on its northern side (Glaciers 1 and 2 in Fig. 1). An epishelf lake $\left(\sim 4.6 \mathrm{~km}^{2}\right.$ in 1992), a freshwater layer dammed by the draft of the ice shelf and permanently stratified over marine water below, existed along the southern coast of the ice shelf until a break-up event in 2005, which drained the fresh water from this area (White, 2012). Since this drainage event, the southern coast of Petersen Bay has been covered by first-year sea ice $(\mathrm{FYI})$ and $\mathrm{MYI}$.

There are few long-term climate records for Ellesmere Island, although weather observations are available from Eureka ( $\sim 300 \mathrm{~km}$ southwest of the Petersen ice shelf) since 1953. According to the measurements collected in Eureka (1954-2007), the average annual air temperature there was $-19.1^{\circ} \mathrm{C}$ over this period. Mean temperatures decreased by a total of $\sim 2^{\circ} \mathrm{C}$ between 1954 and the early 1970s, and except for a brief cooling period in the early 1980s, temperatures have increased consistently since 1972 (total of $3.2^{\circ} \mathrm{C}$; Lesins and others, 2010). An automatic weather station (AWS) in Purple Valley $(\sim 17 \mathrm{~km}$ to the east of the Petersen ice shelf; Fig. 1) has been recording surface air temperatures since June 2009. Between April 2008 and May 2009 this AWS recorded air temperatures at the Serson Ice Shelf, $\sim 72 \mathrm{~km}$ to the west of Purple Valley and $\sim 58 \mathrm{~km}$ to the west of the Petersen ice shelf. Air temperature was measured at two heights at the AWS ( 1 and $2 \mathrm{~m}$ above ground) and hourly surface air temperature was taken as the average of these two measurements. The mean annual surface air 
temperature for the four complete years on record was $-17.7^{\circ} \mathrm{C},-17.3^{\circ} \mathrm{C},-18.8^{\circ} \mathrm{C}$ and $-17.5^{\circ} \mathrm{C}$, for 2009,2010 , 2011 and 2012, respectively. The maximum surface air temperature on record was $11.4^{\circ} \mathrm{C}$ on 18 July 2012, while the minimum was $-47.8^{\circ} \mathrm{C}$ on 7 February 2011.

\section{METHODS}

To assess the characteristics and recent changes of the Petersen ice shelf, this study used a combination of remote sensing and fieldwork. Current surface mass balance was measured at two ablation stakes on the ice-shelf surface between spring 2011 and spring/summer 2012, and a third ablation stake between spring 2012 and spring 2013. The value for surface lowering was converted to units of water equivalent using an ice density of $900 \mathrm{~kg} \mathrm{~m}^{-3}$.

\subsection{Temporal area changes}

Changes in the areal extent of the Petersen ice shelf were determined using georectified aerial photographs (1959, 1974 and 1984), optical satellite imagery from Landsat 7 (1999) and the Advanced Spaceborne Thermal Emission and Reflection Radiometer (ASTER; 2001-03 and 2005-10), and synthetic aperture radar (SAR) satellite imagery from RADARSAT-1 and 2 (2005, 2011 and 2012) (Table 1). Multiple vertical aerial photographs were acquired from the National Air Photo Library in Ottawa, Canada, and scanned at a resolution of $1200 \mathrm{dpi}$ (dots per inch). The 1959 photographic set had the most extensive coverage, excluding only the back of the ice shelf, while the 1974 and 1984 images covered only the very front of the ice shelf. The air photographs were cropped and mosaicked to create one continuous image for each year. Areas with missing coverage were assumed not to have changed.

Both the aerial photography and satellite imagery were georeferenced against a master image (ASTER L1B, 16 July 2009). The images were processed in E5RI ArcGIS 9.3.1 by first projecting the data (World Geodetic System 1984 (WGS84), Universal Transverse Mercator (UTM) zone 17N), and then performing a shift to align the image to the master image. Where necessary, the images were then georectified using a first-order polynomial interpolation with 10-16 ground control points (GCPs). The GCPs were chosen on areas of stable exposed land, and were as widely distributed across the image as possible. Because the 1974 and 1984 air photographs had limited land coverage, distinctive, apparently stable melt ponds on the surface of the ice shelf were also used to provide GCPs for these scenes. The average root-mean-square error (RMSE) for all scenes was $23.4 \mathrm{~m}$, which is considered sufficient given the $15 \mathrm{~m}$ resolution of the master image and the magnitude of the changes being measured (Table 1). For satellite imagery which only required shifting, georectification with GCPs was not required, so no RMSE was recorded.

To calculate change in ice-shelf area over time, the iceshelf extent was digitized in each air photograph or satellite image in ArcGIS 9.3.1. The boundary of the ice shelf was easily discriminated from the surrounding land and other ice types due to the characteristic undulating topography of the ice-shelf surface. In this study the area of the ice shelf was calculated using only the contiguous ice mass, which did not include ice detached from the main ice shelf, even if it was still attached to the coast. A contiguous ice mass includes all portions of the ice shelf in contact, even if the ice was only
Table 1. List of remotely sensed imagery used in the analysis of iceshelf area changes. All images were georeferenced to the 16 July 2009 ASTER image (WGS84, UTM zone 17N)

Sensor/platform Resolution Acquisition date and time GCPs RMSE

m yyyy-mm-dd, hh:mm:ss

$\mathrm{m}$

\begin{tabular}{llccc}
\hline Air photograph* $^{*}$ & 6.61 & $1959-08-13, \mathrm{NA}$ & 10 & 33.25 \\
Air photograph $^{\dagger}$ & 2.25 & $1974-07-11, \mathrm{NA}$ & 16 & 23.67 \\
Air photograph $^{*}$ & 2.11 & $1984-07-23, \mathrm{NA}$ & 11 & 38.22 \\
Landsat-7 ETM+ $^{+}$ & 29.55 & $1999-07-07, \mathrm{NA}$ & $\mathrm{NA}$ & $\mathrm{NA}$ \\
ASTER level 1B & 14.25 & $2001-05-23,22: 28: 36$ & 13 & 14.66 \\
ASTER level 1B & 15.08 & $2002-06-19,21: 31: 31$ & 13 & 15.45 \\
ASTER level 1B & 15.93 & $2003-07-03,22: 49: 29$ & 13 & 14.93 \\
RADARSAT-1 S1 & 12.5 & $2005-03-18,19: 58: 57$ & NA & NA \\
ASTER level 1B & 14.21 & $2005-06-03,22: 18: 20$ & NA & NA \\
RADARSAT-1 S7 & 12.5 & $2005-08-18,22: 16: 33$ & NA & NA \\
RADARSAT-1 S1 & 12.5 & $2005-08-23,19: 50: 28$ & NA & NA \\
RADARSAT-1 S1 & 12.5 & $2005-09-26,19: 58: 42$ & NA & NA \\
ASTER level 1B & 14.21 & $2006-07-24,22: 18: 51$ & NA & NA \\
ASTER level 1B & 16.21 & $2007-07-19,23: 08: 20$ & NA & NA \\
ASTER level 1B & 18.68 & $2008-08-22,00: 03: 37$ & NA & NA \\
ASTER level 1B & 15 & $2009-07-16,20: 41: 21$ & NA & NA \\
ASTER level 1B & 17 & $2010-07-02,23: 14: 19$ & NA & NA \\
ASTER level 1B & 14.21 & $2010-07-19,22: 19: 01$ & NA & NA \\
RADARSAT-2 UF & 2.24 & $2011-04-01,20: 39: 28$ & NA & NA \\
RADARSAT-2 UFW & 2.40 & $2012-02-03,20: 56: 10$ & NA & NA \\
RADARSAT-2 FQW & 7.65 & $2012-08-24,20: 35: 23$ & NA & NA \\
& & & & \\
\hline
\end{tabular}

Note: NA: not applicable.

*Roll No. A16724; photograph Nos. 63, 64.

'Roll No. A23943; photograph Nos. 55, 57, 58, 60

Roll No. A26535; photograph Nos. 160, 162, 171.

weakly refrozen in place following a break-up event. The digitized polygons produced from each image were differenced to determine change in ice-shelf extent over time.

\subsection{Ice-shelf thickness}

A pulseEKKO PRO $250 \mathrm{MHz}$ ground-penetrating radar (GPR) system (Sensors \& Software, Inc.) was used to measure ice thickness across the Petersen ice shelf in May 2011. A time window of $1500 \mathrm{~ns}$ was set for the GPR, with a sampling interval of $0.40 \mathrm{~ns}$ and antenna separation of $0.40 \mathrm{~m}$. The GPR system was custom-fitted into a sled and towed behind a snowmobile at $\sim 20 \mathrm{~km} \mathrm{~h}^{-1}$. A grid-like pattern was followed where possible, but steep local topography and safety considerations prevented this in some locations, particularly near the ice-shelf front (Fig. 2). An integrated singlefrequency GPS receiver (GPS-NX02, StarGPS) was connected to the GPR system and used to record the position of each GPR trace to an accuracy of $\sim 10 \mathrm{~m}$. Ice-shelf ice was distinguishable from surrounding ice types by its undulating topography in satellite imagery, so that traces not located on this ice type were subsequently removed in ArcGIS; however, sea ice may have been included in the thickness measurements at the boundary of the ice shelf and sea ice.

The GPR data were processed with a dewow time filter and trace differencing in EKKO_View Deluxe Version 1.4 (Sensors \& Software, 2003). Repeat traces, which occurred while the GPR was immobile, were deleted. IcePicker Release 4 (Sensors \& Software, Inc.) was then used to pick the snow/ice interface and bed reflections to derive ice thicknesses. Based on previous GPR measurements in the study region, an electromagnetic wave velocity of $2.00 \times 10^{8} \mathrm{~m} \mathrm{~s}^{-1}$ was used for snow, $1.50 \times 10^{8} \mathrm{~m} \mathrm{~s}^{-1}$ for 


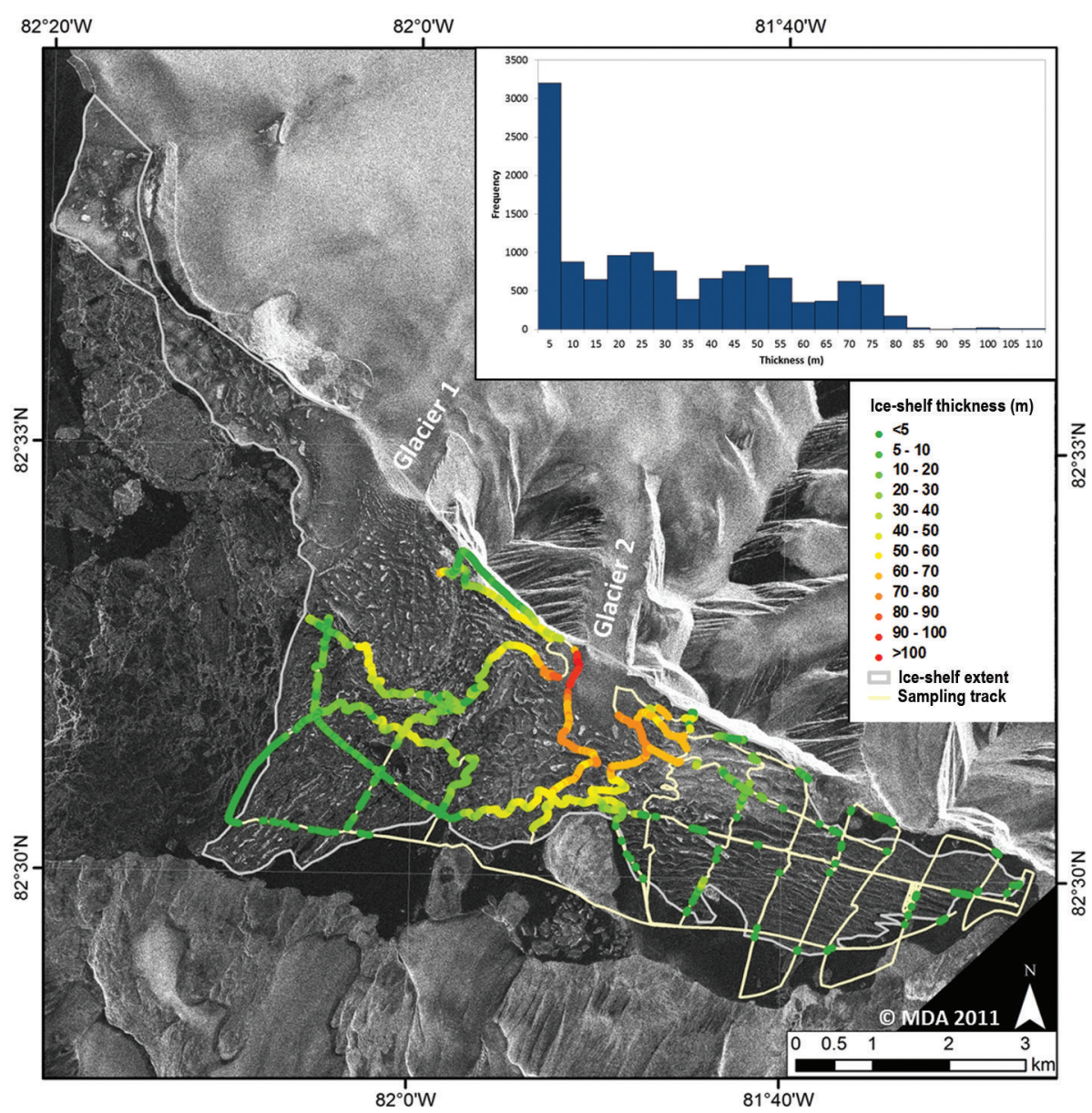

Fig. 2. Ice thicknesses across the Petersen ice shelf derived from GPR surveys conducted in May 2011 overlaid on an Ultra-Fine mode RADARSAT-2 HH image (1 April 2011). Inset: histogram illustrating the frequency of ice-shelf thicknesses.

sea ice, and $1.70 \times 10^{8} \mathrm{~m} \mathrm{~s}^{-1}$ for ice-shelf ice (Mortimer and others, 2012; Pope and others, 2012). Pope and others (2012) verified the accuracy of the $1.50 \times 10^{8} \mathrm{~m} \mathrm{~s}^{-1}$ value by comparing GPR-derived thickness measurements to borehole measurements in sea ice in Yelverton Bay and Yelverton Inlet. Mortimer and others (2012) confirmed the $1.70 \times 10^{8} \mathrm{~ms}^{-1}$ value by conducting a commonmidpoint survey on the Milne Fiord epishelf lake. The snow-to-ice (i.e. near-surface) and ice-to-underlying-water (i.e. basal) interfaces were processed separately to isolate ice thickness data.

The total error for the ice thicknesses recorded across the Petersen ice shelf was determined from the GPR system resolution and reflection picking error. The GPR system resolution is typically assumed to be $10 \%$ of the transmitted wavelength (Bogorodsky and others, 1985), which yields an error of $\pm 0.07 \mathrm{~m}$ at a center frequency of $250 \mathrm{MHz}$. To examine reflection picking error a cross-point analysis was conducted to determine the difference between ice thicknesses derived from independent transects that crossed within $2 \mathrm{~m}$ of each other. A total of 16 cross points were identified, 12 across the ice shelf and 4 over the adjacent epishelf lake. Ice-shelf thickness error, which was determined by adding $0.07 \mathrm{~m}$ (system resolution error) to the difference between the cross-point measurements, varied between $0.1 \%$ and $11.7 \%$ of ice thickness, with a mean of $3.9 \%(0.32 \mathrm{~m})$. To provide conservative estimates of mass fluxes from the tributary glacier, the maximum ice thickness error of $11.7 \%$ was used.

\subsection{Ice motion and mass fluxes}

The surface velocity structure of the ice shelf and tributary glaciers was determined from speckle tracking of a pair of RADARSAT-2 Wide Ultra-Fine mode images acquired on 25 April and 19 May 2012. The speckle-tracking script was run in MATLAB ${ }^{\circledR}$, and uses a two-dimensional crosscorrelation algorithm to estimate the relative motion of ice masses from pairs of SAR imagery (Short and Gray, 2005; Van Wychen and others, 2012). The images were acquired prior to the melt season to ensure good coherence. Surface displacement was determined in both azimuth and range directions using an image chip size of $301 \times 301$ pixels. A $1: 250000$ Canadian Digital Elevation Dataset, resampled to $100 \mathrm{~m}$ grid spacing, was applied to the output of the image cross-correlation to remove the topographic component of the slant range displacement, and thereby facilitate the conversion to ground range displacement. The displacements in range and azimuth were calibrated over areas with known zero motion such as rock outcrops. Velocities were calculated based on this calibration and converted to annual values. Obviously erroneous points were identified and deleted manually in ArcGIS where flow direction did not follow the surrounding topography, and/or where flow vectors changed dramatically in magnitude or direction, or were inconsistent with adjacent vectors (Van Wychen and others, 2012).

The velocities were verified against differential GPS (dGPS) measurements of the change in location of two ablation stakes on the ice-shelf surface in May 2011 and May/July 


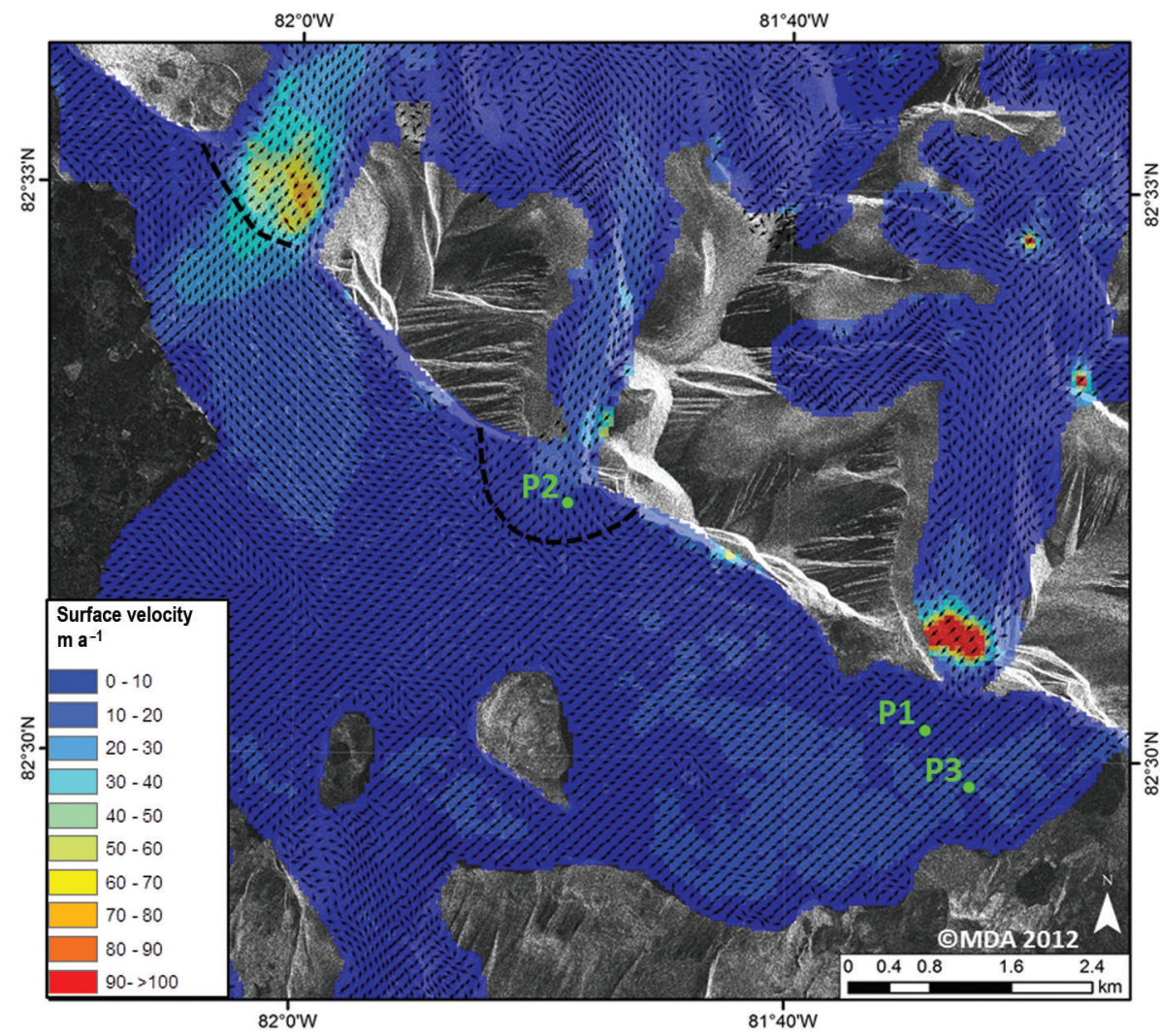

Fig. 3. Surface velocities of the Petersen ice shelf and surrounding glaciers derived from speckle tracking of Wide Ultra-Fine mode RADARSAT-2 scenes (25 April to 19 May 2012), overlaid on a Wlde Ultra-Fine mode RADARSAT-2 HH image (3 February 2012). P1 and P2 indicate ablation stakes measured over 2011/12, while P3 was measured over 2012/13. The dashed black lines represent the location of the flux gates.

2012 (P1 and P2; Fig. 3). Positions were measured with a Trimble R7 dGPS receiver with a minimum occupation time of $20 \mathrm{~min}$, and processed using the Precise Point Positioning service of Natural Resources Canada. This provided an estimated horizontal positional accuracy of 2-3 cm.

A final velocity map was generated in ArcGIS using an inverse distance weighting (IDW) algorithm to interpolate the point velocity values derived from the speckle tracking to a $50 \mathrm{~m}$ pixel raster (ArcGIS, 2009). IDW provides a conservative approach to interpolation as it does not allow new values to exceed those in the original dataset (ArcGIS, 2009). Error was calculated from the apparent motion derived from 43994 speckle-tracking matches over stable bedrock outcrops. The mean error using this method was $5.06 \mathrm{~m} \mathrm{a}^{-1}$, with a standard deviation of $3.65 \mathrm{~m} \mathrm{a}^{-1}$.

The velocity derived from speckle tracking was combined with the ice thickness measurements to estimate the mass input from Glaciers 1 and 2 to the ice shelf (note that Glacier 3 terminates in an ice cliff and does not currently provide input to the ice shelf). Flux gates were defined along the boundary of Glaciers 1 and 2 where they meet the ice shelf (Fig. 3), with Glacier 1 separated into six 250 m segments, and Glacier 2 into eight $250 \mathrm{~m}$ segments. Because no thickness data were available for Glacier 1, three flux scenarios were generated with assumed thicknesses of 50, 75 and $100 \mathrm{~m}$ based on the range of ice thicknesses measured on Glacier 2 ( $\sim 55-106 \mathrm{~m})$. To determine ice thicknesses across the flux gate of Glacier 2, the GPR points nearest to each $250 \mathrm{~m}$ segment were used to determine a mean thickness based on a linear interpolation. The velocity across each segment was determined by calculating the mean of the nearest velocity points (within $40 \mathrm{~m}$ ) of each flux gate. For each $250 \mathrm{~m}$ segment the following equations were used to generate lower $\left(Q_{\min }\right)$ and upper $\left(Q_{\max }\right)$ estimates of ice discharge $(Q)$ :

$$
\begin{gathered}
Q_{\min }=\left(0.8\left(V-V_{\text {error }}\right)\right) \cdot\left(H-H_{\text {error }}\right) \cdot(W) \\
Q_{\max }=\left(V+V_{\text {error }}\right) \cdot\left(H+H_{\text {error }}\right) \cdot(W)
\end{gathered}
$$

where $V$ is surface velocity, $V_{\text {error }}$ is velocity error as discussed above $\left( \pm 5.06 \mathrm{~m} \mathrm{a}^{-1}\right), H$ is ice thickness, $H_{\text {error }}$ is ice thickness error as discussed in Section $4.2( \pm 11.7 \%)$ and $W$ is the segment width $(250 \mathrm{~m})$. Surface velocities were converted to a depth-averaged velocity of $80 \%$ for lower flux values based on the recommendation of Paterson (1994). For the upper flux values, surface velocities are assumed to be representative of the velocities of the entire ice column to account for the possibility of motion entirely by basal sliding (Van Wychen and others, 2012). Flux errors were only calculated for Glacier 2 due to the use of hypothetical ice thicknesses for Glacier 1. The flux through each segment was summed to determine the total discharge across the $1500 \mathrm{~m}$ gate at Glacier 1 and $2000 \mathrm{~m}$ gate at Glacier 2. It should be noted that the flux calculations are based on winter velocities (25 April to 19 May 2012).

\subsection{Climate data}

To examine climate variability since 1948, US National Centers for Environmental Prediction (NCEP)/National Center for Atmospheric Research (NCAR) Reanalysis monthly mean air temperature data were downloaded from the US National Oceanic and Atmospheric Administration (NOAA) Earth System Research Laboratory website 

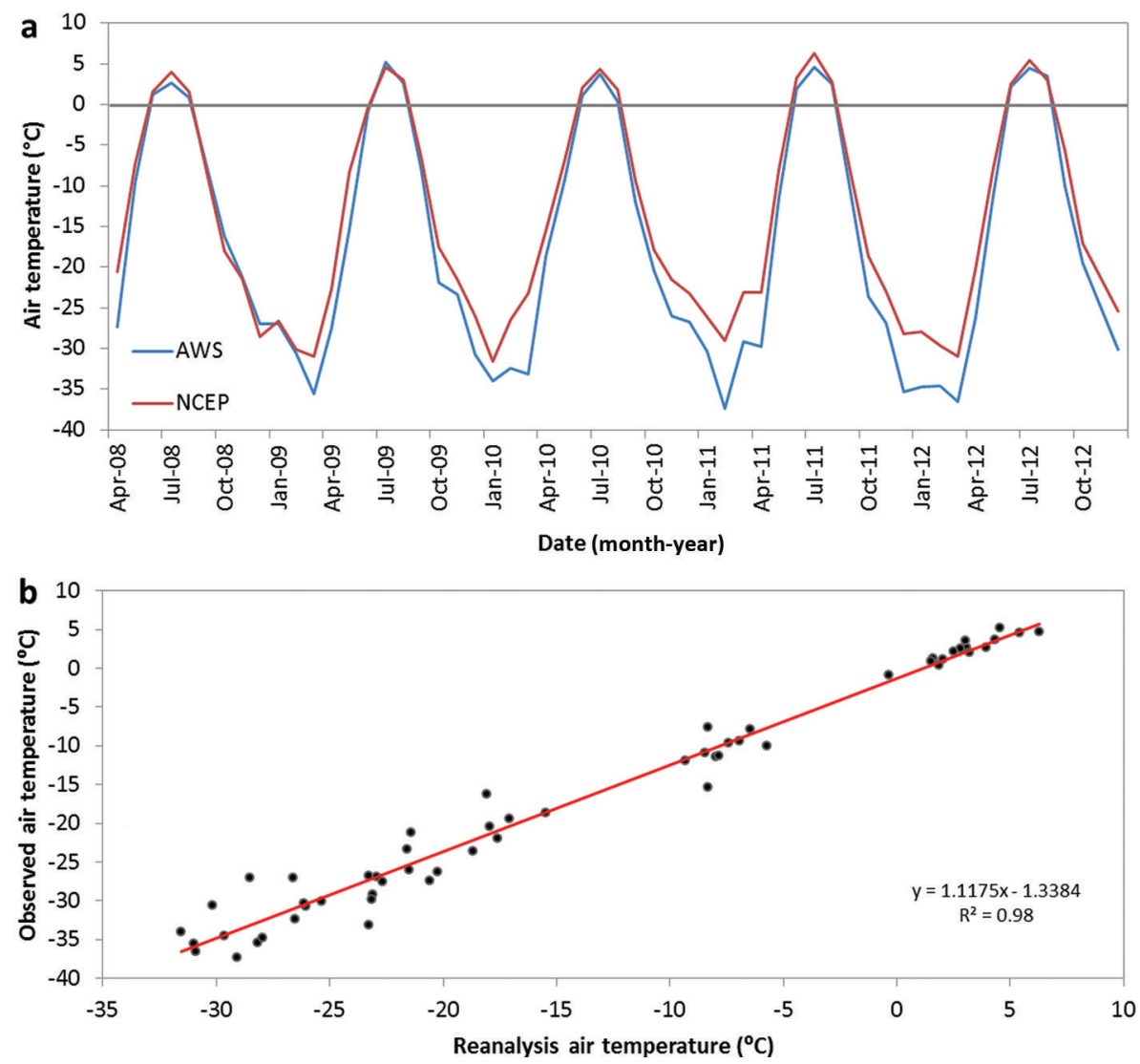

Fig. 4. Comparison of NCEP/NCAR Reanalysis data and AWS data from 2008 to 2012. (a) Time series of mean monthly surface air temperature recorded by the Purple Valley AWS (2 April 2008 to 31 December 2012) and derived from the reanalysis data for 2008-12. November 2012 mean monthly value omitted due to sensor error. (b) Scatter plot of the observed mean monthly air temperature and the reanalysis data.

(http://www.esrl.noaa.gov/psd/data/reanalysis/reanalysis. shtml). These data are drawn from an assimilated gridded $\left(2.5^{\circ} \times 2.5^{\circ}\right.$ grid) dataset, based on observations from meteorological stations with a numerical weather prediction model (Kalnay and others, 1996). For this study, mean monthly surface (1000 mbar) air temperatures from 1948 to 2012 were downloaded for the gridcell centered on the Petersen ice shelf. This climate dataset was selected based on its temporal range and good agreement with automatic weather station (AWS) data collected from Purple Valley (Fig. 1). A comparison of the 2008-12 monthly mean data shows that the reanalysis data have a positive bias compared to the observational data, particularly during winter months (Fig. 4a). A linear regression between the reanalyzed and observed temperature is significant $\left(R^{2}=0.98, p<0.0001\right)$ (Fig. $4 \mathrm{~b}$ ), with a RMSE of $3.97^{\circ} \mathrm{C}$. This suggests that the reanalysis data can be used to model the variability and trends in air temperature at the Petersen ice shelf, although caution is required when using them to assess absolute air temperature. This model and reanalysis data were used to estimate the surface air temperature in the vicinity of the Petersen ice shelf from 1948 to 2012 on a monthly, seasonal (summer: June-August; autumn: September-November; winter: December-February; spring: March-May) and annual basis.

\section{RESULTS}

\subsection{Area changes}

The aerial photographs and satellite imagery indicate that there was a cumulative $\sim 1.5 \mathrm{~km}^{2}$ increase in area of the
Petersen ice shelf between $1959\left(48.40 \mathrm{~km}^{2}\right)$ and 1999 $\left(49.87 \mathrm{~km}^{2}\right.$ ) (Fig. 5a; Table 2). This increase was largely attributable to a change of the ice-shelf front due to a $\sim 0.25 \mathrm{~km}$ advance in the northwestern portion of Glacier 1 (Fig. 5a). Along the southern margin of the ice shelf, to the east of the islands, there was a $0.76 \mathrm{~km}^{2}$ decrease in area between 1959 and 1999. The years 1999-2005 represented a period of little change to the ice-shelf area $\left(-1.41 \mathrm{~km}^{2}\right.$ to $+0.96 \mathrm{~km}^{2}$; Table 2). However, since 2005 there have been more dramatic changes in extent than previously observed; the following subsections describe years when annual losses have exceeded $2 \mathrm{~km}^{2}$.

Between 3 June $2005\left(48.92 \mathrm{~km}^{2}\right)$ and 24 July 2006 $\left(40.84 \mathrm{~km}^{2}\right)$ there was an $8.07 \mathrm{~km}^{2}(16.5 \%)$ reduction in iceshelf area, reflecting the first major calving event from the Petersen ice shelf since 1959. This loss occurred primarily at the ice-shelf front between 5 and 18 August 2005, at the same time as the loss of $>690 \mathrm{~km}^{2}$ of 55-60-year-old MLSI from Yelverton Bay directly in front of the Petersen ice shelf (Copland and others, 2007; Pope and others, 2012). A sequence of RADARSAT-1 images from 18 March, 18 August, 23 August and 26 September 2005 helps in understanding the progression of this calving event (Fig. 6). In the 18 March scene (Fig. 6a), the ice shelf is intact, with the freshwater epishelf lake behind it characterized by bright backscatter in the SAR image (White, 2012). A fracture, which first appeared in 1999 satellite imagery, can be seen running north-south down the center of the ice shelf. In the 18 August 2005 satellite scene (Fig. 6b), the MLSI in front of the ice shelf is gone and replaced by open water (appearing smooth and 

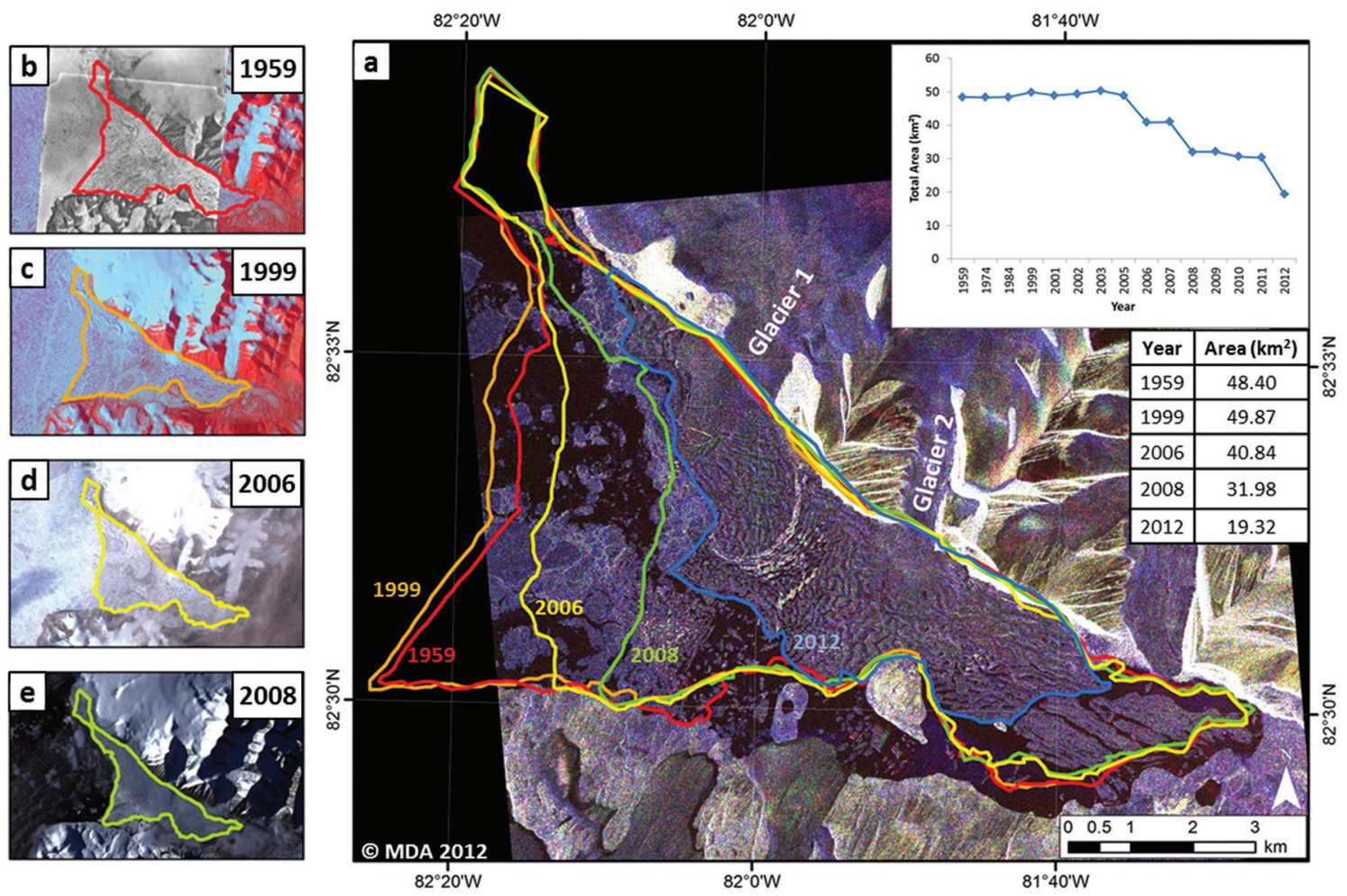

Fig. 5. Changes in Petersen ice shelf extent through time: (a) RADARSAT-2 Wide Fine Quad-polarization mode (24 August 2012); (b) aerial photograph (13 August 1959) with Landsat Enhanced Thematic Mapper Plus (ETM+) (7 July 1999) as background; (c) Landsat ETM+ (7 July 1999); (d) ASTER L1B (24 July 2006); and (e) ASTER L1B (22 August 2008).

dark in the SAR imagery), with the front of the ice shelf disintegrated into hundreds of pieces up to $0.48 \mathrm{~km}^{2}$ in area. By 23 August 2005, an ice island measuring $6.47 \mathrm{~km}^{2}$ had calved along the pre-existing north-south fracture near the center of the ice-shelf front (Fig. 6c). Pack ice filled the majority of the bay at the front of the ice shelf at this time. However, complete breakaway of the ice island was prevented by the pressure of the pack ice which had moved southeast by 26 September 2005 (Fig. 6d). The pressure applied by the pack ice caused the fracture to be closed and the ice island to freeze back in place. We therefore consider it to be part of the ice-shelf area at the end of September 2005, until it calved in 2008.

A meandering fissure along the southern margin of the ice shelf, from the epishelf lake to the ocean, first appeared at the time of the ice-shelf break-up in August 2005 (Fig. 6b). This allowed the epishelf lake to completely drain away. The loss of this lake was confirmed through backscatter analysis of SAR data, which showed a shift from high backscatter $(>-6 \mathrm{~dB})$ consistent with freshwater ice to lower backscatter values consistent with sea ice (White, 2012). Areas of open water were also observable in the epishelf lake area at this time, identifiable by a smooth dark texture in the RADARSAT-1 image.

The Petersen ice shelf underwent a second major calving event in summer 2008, reducing in area from $40.97 \mathrm{~km}^{2}$ to $31.98 \mathrm{~km}^{2}(21.9 \%$ reduction in remaining area) between 19 July 2007 and 22 August 2008 (Fig. 5). This loss occurred primarily due to calving along the pre-existing fracture at the ice-shelf front, causing the release and disintegration of the ice island that was trapped since September 2005. The 22 August 2008 ASTER image shows ice islands with individual areas up to $0.9 \mathrm{~km}^{2}$ surrounded by open water in Yelverton Bay (Fig. 5e). Open water was also visible (under cloud) south of the ice shelf in Petersen Bay along with an open-water fissure between the coastline and the ice shelf, as in 2005. The ice loss from the Petersen ice shelf in summer 2008 coincided with further loss of MLSI remnants from Yelverton Inlet at this time (Pope and others, 2012).

Further major calving occurred from the ice shelf in summer 2011. Between 1 April 2011 and 3 February 2012 the surface area decreased from $30.29 \mathrm{~km}^{2}$ to $24.81 \mathrm{~km}^{2}$, a total loss of $5.48 \mathrm{~km}^{2}$ (Table 2). These losses occurred from both the front and southern flank of the ice shelf, which resulted in an $18 \%$ reduction in remaining area. A loss of

Table 2. Petersen ice shelf area changes from 1959 to 2012

\begin{tabular}{lccc}
\hline Time period & Time interval & $\begin{array}{c}\text { Total } \\
\text { ice-shelf area } \\
\mathrm{km}^{2}\end{array}$ & $\begin{array}{c}\text { Total } \\
\text { area change } \\
\mathrm{km}^{2}\end{array}$ \\
\hline yug 1959-Jul 1974 & 14.9 & 48.37 & -0.03 \\
Jul 1974-Jul 1984 & 10.0 & 48.42 & +0.05 \\
Jul 1984-Jul 1999 & 15.0 & 49.87 & +1.45 \\
Jul 1999-May 2001 & 1.9 & 48.88 & -0.99 \\
May 2001-May 2002 & 1.0 & 49.36 & +0.48 \\
May 2002-Jul 2003 & 1.1 & 50.32 & +0.96 \\
Jul 2003-Jun 2005 & 1.9 & 48.92 & -1.41 \\
Jun 2005-Jul 2006 & 1.1 & 40.84 & -8.07 \\
Jul 2006-Jul 2007 & 1.0 & 40.97 & +0.13 \\
Jul 2007-Aug 2008 & 1.1 & 31.98 & -8.99 \\
Aug 2008-Jul 2009 & 0.9 & 32.08 & +0.10 \\
Jul 2009-Jul 2010 & 1.0 & 30.68 & -1.40 \\
Jul 2010-Apr 2011 & 0.8 & 30.29 & -0.38 \\
Apr 2011-Feb 2012 & 0.8 & 24.81 & -5.48 \\
Feb 2012-Aug 2012 & 0.6 & 19.32 & -5.49 \\
\hline
\end{tabular}



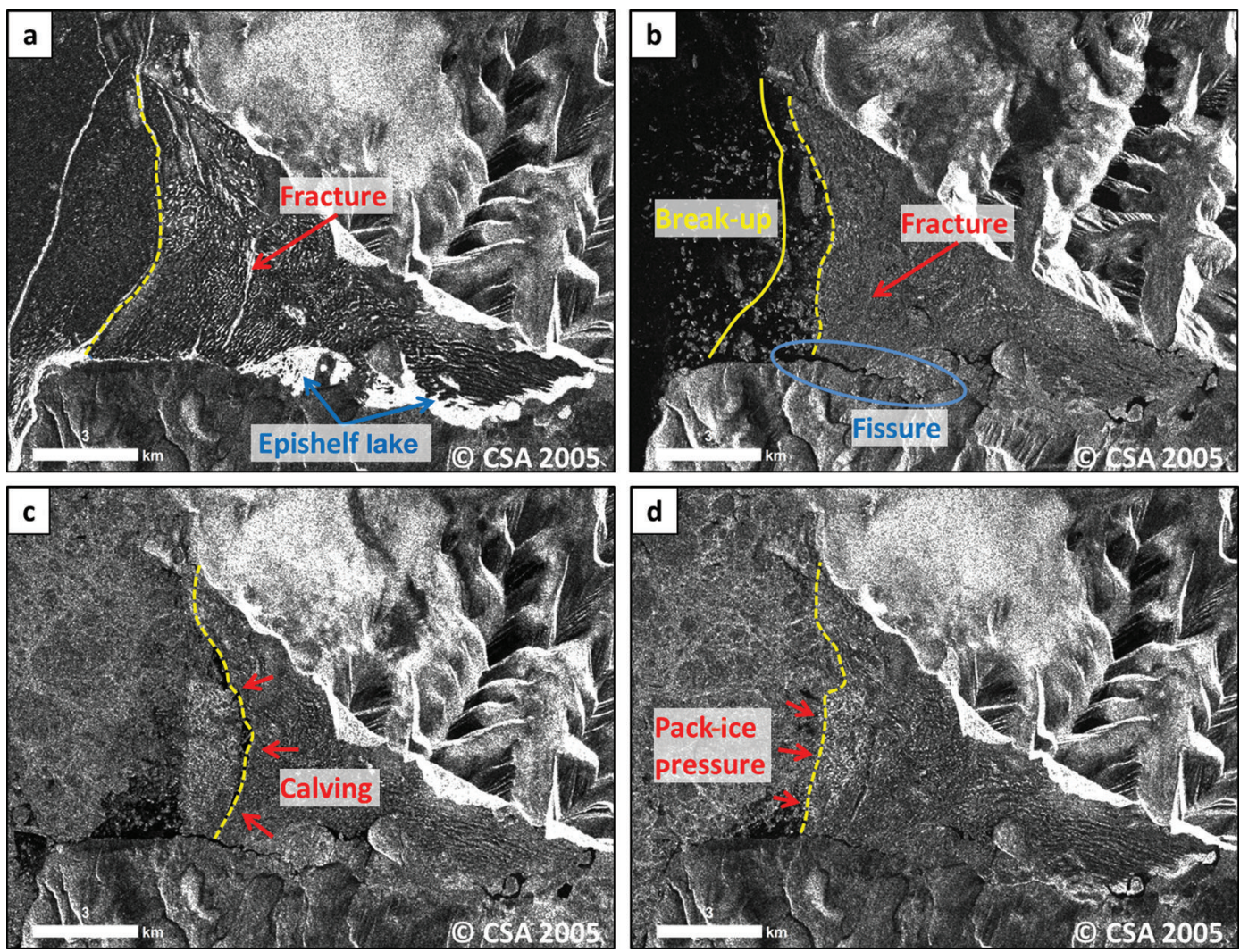

Fig. 6. Annotated Standard RADARSAT-1 imagery indicating the changes that occurred at the Petersen ice shelf in summer 2005: (a) 18 March 2005; (b) 18 August 2005; (c) 23 August 2005; and (d) 26 September 2005.

$1.75 \mathrm{~km}^{2}$ occurred at the seaward front, including the separation between the main ice shelf and a remnant piece on the northwest corner along the edge of Cape Evans ice cap. Losses along the southern edge of the ice shelf amounted to $3.73 \mathrm{~km}^{2}$.

RADARSAT-2 imagery from 3 February 2012 and 24 August 2012 reveals a loss of $5.49 \mathrm{~km}^{2}$ over this period. This loss, which occurred predominantly at the back of the ice shelf, resulted in the production of several ice islands up to $\sim 1.13 \mathrm{~km}^{2}$ in area (Fig. 5a). The RADARSAT-2 image also revealed open water surrounding the ice shelf, including the southern coast of Petersen Bay and across the outlet into Yelverton Bay. Following a calving event, the remaining ice shelf was mainly limited to the region adjacent to the termini of Glaciers 1 and 2.

\subsection{Ice-shelf thickness}

The GPR-derived mean thickness of the Petersen ice shelf was $29 \mathrm{~m}$ in spring 2011, with a standard deviation of $24 \mathrm{~m}$ (Fig. 2; Table 3). The thickness increased with proximity to the two tributary glaciers. This was particularly true for the terminus of Glacier 2, which ranged in thickness between 34 and $106 \mathrm{~m}$, with a mean thickness of $70 \mathrm{~m}$. Away from the glacier termini ice thickness was lower, ranging between $<1$ and $72 \mathrm{~m}$, with a mean of $23 \mathrm{~m}$. The sea ice to the south of the ice shelf (thickness not shown on the sampling track in Fig. 2) had a mean thickness of $0.8 \mathrm{~m}$ and standard deviation of $0.2 \mathrm{~m}$, with the thickest areas of $\sim 0.9 \mathrm{~m}$ at the back of the ice shelf. Ice cores drilled in a trough at the rear of the ice shelf, and in sea ice along the south of the ice shelf (in May 2011 and 2012), confirmed the presence of thin ice in these regions, with thicknesses of 1.44 and $1.28 \mathrm{~m}$, respectively.
Many thinner regions (i.e. the eastern half of the ice shelf; Fig. 2) lacked bottom reflections. Past studies have attributed weak or missing bottom reflections on other Arctic ice shelves to signal attenuation caused by saline intrusion into basal ice, such as at the Ward Hunt Ice Shelf (HattersleySmith and others, 1969; Prager, 1983; Narod and others, 1988). In particular, weak soundings at the western Ward Hunt Ice Shelf were attributed to brine inclusion in the basement ice with a mean bulk salinity of $2.22 \pm 0.6 \mathrm{psu}$ (Lyons and others, 1971; Jeffries and others, 1988). Given that the bulk salinity below a depth of 5-6 $\mathrm{m}$ identified in our ice core on the Petersen ice shelf was $>2$ psu, it is likely that this is the cause of the signal attenuation there.

\subsection{Surface mass balance and mass flux}

To complement the changes in extent described above, the surface mass balance and flux from Glaciers 1 and 2

Table 3. Petersen ice shelf thickness statistics, determined from GPR measurements in spring 2011

\begin{tabular}{lc}
\hline Statistic & Value \\
\hline Number of traces & 12746 \\
Minimum & $<1 \mathrm{~m}$ \\
Maximum & $106.26 \mathrm{~m}$ \\
Mean & $28.52 \mathrm{~m}$ \\
Median & $23.56 \mathrm{~m}$ \\
Standard deviation & $23.99 \mathrm{~m}$ \\
Upper quartile & $47.40 \mathrm{~m}$ \\
Lower quartile & $5.14 \mathrm{~m}$
\end{tabular}


were estimated (Fig. 3). Ablation stake P2 underwent surface ablation of $1.22 \mathrm{mw} . e . \mathrm{a}^{-1}$, while stake P1 lost $1.07 \mathrm{~m}$ w.e. $\mathrm{a}^{-1}$, between May 2011 and May 2012. If the mean of these ablation rates is averaged over the 2011/12 ice-shelf area $\left(24.81 \mathrm{~km}^{2}\right.$ in February 2012) the rate of mass loss equates to $28.45 \mathrm{Mta}^{-1}$. This likely provides a conservative estimate of recent losses as the ablation rate at stake P3 at the rear of the ice shelf was $1.30 \mathrm{~m}$ w.e. $\mathrm{a}^{-1}$ between May 2012 and May 2013.

The speckle-tracking results show the surface velocity of the ice shelf and tributary glaciers, standardized to values of $\mathrm{ma}^{-1}$ (Fig. 3). A comparison with the dGPS measurements showed that stake P2 moved south $\left(184.7^{\circ}\right)$ at a velocity of $9.0 \mathrm{~m} \mathrm{a}^{-1}$, while the nearest speckle-tracking point (within $50 \mathrm{~m}$ ) displayed a movement of $7.6 \mathrm{~m} \mathrm{a}^{-1}$ at a bearing of $177.3^{\circ}$. At ablation stake P1, the motion was $4.1 \mathrm{ma}^{-1}$ at a bearing of $154.6^{\circ}$, while the nearest speckle-tracking point moved $9.6 \mathrm{~m} \mathrm{a}^{-1}$ at a bearing of $55.8^{\circ}$. These differences are within the error limits of the speckle-tracking method, and may also be due to the difference in time between the measurement dates for the ablation stakes ( $\sim 1$ year) and speckle tracking (24 days).

The mean surface velocity along the main trunk of Glacier 1 was $33 \mathrm{ma}^{-1}$, while it was $14 \mathrm{ma}^{-1}$ for Glacier 2 (Fig. 3; Table 4). When these velocities are combined with the GPR thickness measurements, the total flux into the ice shelf from Glacier 2 is estimated at $0.08-1.52 \mathrm{Mt} \mathrm{a}^{-1}$. If this volume is distributed evenly across the February 2012 ice-shelf area $\left(24.81 \mathrm{~km}^{2}\right)$, it equates to an area-averaged thickness change equivalent of $0.004-0.07 \mathrm{~m} \mathrm{a}^{-1}$. Using three depth scenarios (50, 75 and $100 \mathrm{~m}$ ) for Glacier 1, total estimated fluxes ranged between 1.10 and $4.12 \mathrm{Mta}^{-1}$, equivalent to areaaveraged ice thicknesses of $0.05-0.18 \mathrm{~m} \mathrm{a}^{-1}$ (Table 4).

\subsection{Climate analysis}

Mean annual surface air temperatures at the Petersen ice shelf increased by $3.3^{\circ} \mathrm{C}$ between 1948 and 2012 (Fig. 7a). This increase equates to a warming trend of $0.5^{\circ} \mathrm{C}$ (decade $)^{-1}$ $\left(R^{2}=0.52, p<0.0001\right)$. Nine of the top ten highest mean annual temperatures occurred over the past decade, with 2010 being the warmest year at $-16.9^{\circ} \mathrm{C}$. The year 2011 was notable for record high temperatures for March $\left(-27.2^{\circ} \mathrm{C}\right)$, June $\left(-2.2^{\circ} \mathrm{C}\right)$ and July $\left(5.7^{\circ} \mathrm{C}\right)$. Since 2005 , mean annual temperatures have consistently exceeded the long-term mean $\left(-20.3^{\circ} \mathrm{C}\right.$ from 1948 to 2012$)$ by $1.5-3.4^{\circ} \mathrm{C}$. The highest mean summer air temperatures were recorded in $2011\left(3.2^{\circ} \mathrm{C}\right), 2012\left(2.7^{\circ} \mathrm{C}\right)$ and $2005\left(2.2^{\circ} \mathrm{C}\right)$, and every summer since 2000 the temperature has exceeded the
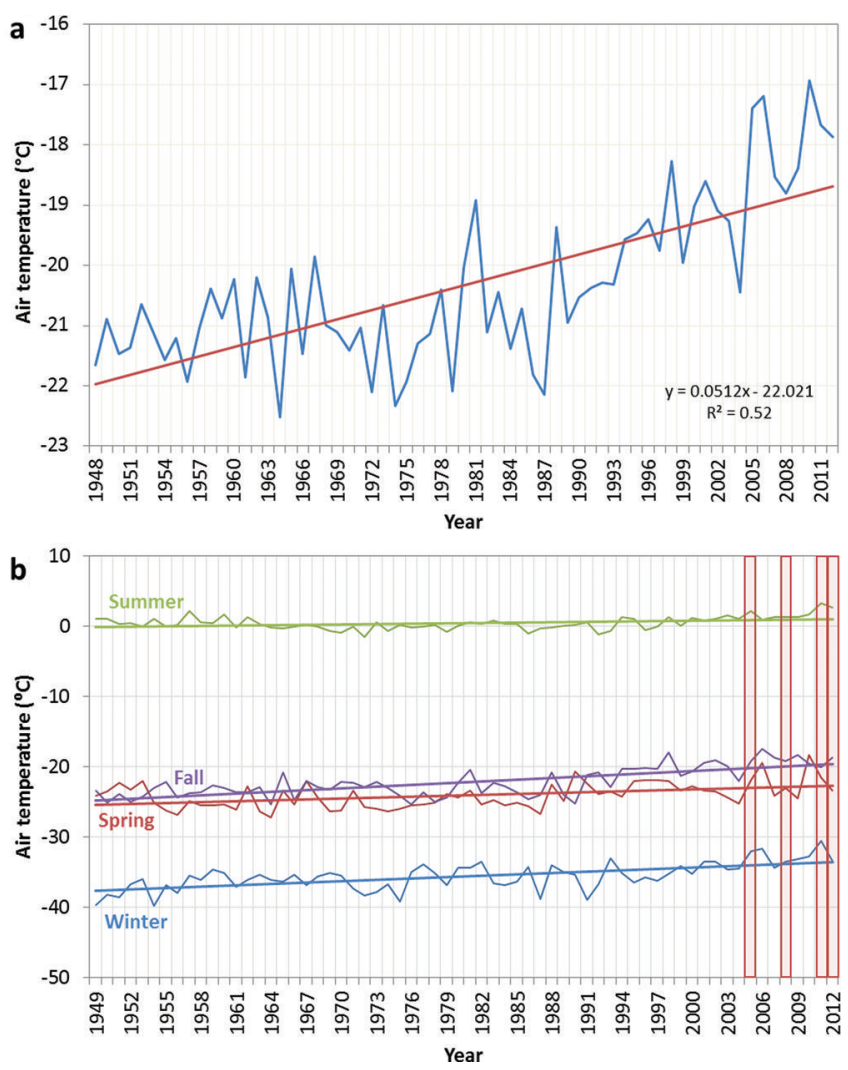

Fig. 7. Estimated surface air temperature from 1948 to 2012 for the Petersen ice shelf. (a) Mean annual air temperature. (b) Mean summer, autumn, winter and spring air temperatures; solid horizontal lines indicate long-term mean values; vertical red boxes indicate years with major break-up events.

long-term mean summer temperature $\left(0.5^{\circ} \mathrm{C}\right)$ by $0.4-2.8^{\circ} \mathrm{C}$ (Fig. 7b; Table 5). Despite the record-breaking mean summer air temperatures, the most significant long-term seasonal trend in mean air temperatures has been observed in autumn, with a $5.0^{\circ} \mathrm{C}$ increase from 1948 to 2012, compared to a $1.0^{\circ} \mathrm{C}$ increase in mean summer air temperatures (Fig. 7b).

\section{DISCUSSION}

Over the past 53 years, major calving events of the Petersen ice shelf occurred in summers $2005\left(8.07 \mathrm{~km}^{2}\right), 2008$ $\left(8.99 \mathrm{~km}^{2}\right), 2011\left(5.48 \mathrm{~km}^{2}\right)$ and $2012\left(5.49 \mathrm{~km}^{2}\right)$. All four of these years had particularly high mean summer air temperatures $\left(0.8-2.8^{\circ} \mathrm{C}\right.$ above $1948-2012$ summer mean),

Table 4. Glacier velocities, total fluxes and area-averaged thickness contributions to the Petersen ice shelf from Glaciers 1 and 2 (Fig. 1). Ice thicknesses derived and estimated from GPR measurements; velocities derived from speckle tracking of RADARSAT-2 Wide Ultra-Fine mode images (25 April to 19 May 2012) as described in Sections 4.2 and 4.3

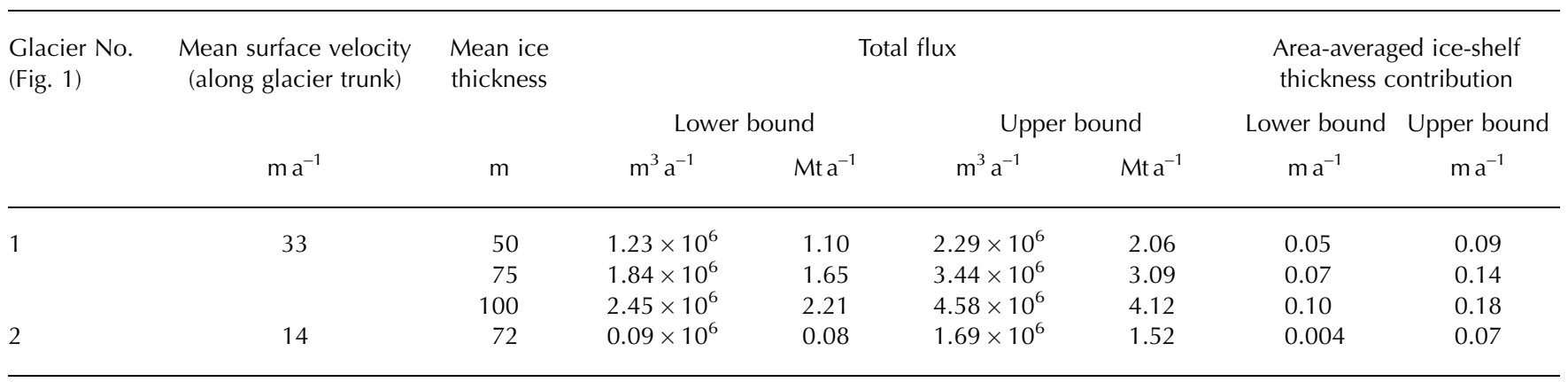


Table 5. Observations of open water and estimated summer surface air temperature anomaly (1948-2012), during years of ice-shelf change

\begin{tabular}{|c|c|c|c|c|c|}
\hline \multirow[t]{2}{*}{ Summer year } & $\begin{array}{l}\text { Ice-shelf } \\
\text { change }\end{array}$ & $\begin{array}{l}\text { Presence of } \\
\text { open water }\end{array}$ & Evidence for open water & Sensor, date & $\begin{array}{l}\text { Temperature } \\
\text { anomaly }\end{array}$ \\
\hline & $\mathrm{km}^{2}$ & & & & ${ }^{\circ} \mathrm{C}$ \\
\hline 1999/2000 & Loss $(0.99)$ & Yes & $\begin{array}{l}\text { New ice islands } \\
\text { MLSI fracture }\end{array}$ & ASTER L1B, 25 Jun 2001 & 0.2 \\
\hline 2001 & Gain (0.48) & No & $\begin{array}{l}\text { Ice islands remain motionless } \\
\text { MLSI present }\end{array}$ & ASTER L1B, 10 May 2002 & 0.4 \\
\hline 2002 & Gain (0.96) & No & $\begin{array}{l}\text { Ice islands remain motionless } \\
\text { MLSI present }\end{array}$ & ASTER L1B, 50 May 2003 & 0.6 \\
\hline $2003 / 04$ & Loss $(1.41)$ & No & $\begin{array}{l}\text { Ice islands remain motionless } \\
\text { MLSI present }\end{array}$ & ASTER L1B, 3 Jun 2005 & 0.8 \\
\hline 2005 & Loss (8.07) & Yes & Loss of MLSI & ASTER L1B, 24 Jul 2006 & 1.7 \\
\hline 2006 & Gain (0.13) & No & $\begin{array}{c}\text { Ice islands and MLSI fragments remain } \\
\text { motionless }\end{array}$ & ASTER L1B, 14 Jul 2007 & 0.4 \\
\hline 2008 & Loss (8.99) & Yes & $\begin{array}{c}\text { Widespread visible open water in Petersen } \\
\text { Bay/Yelverton Bay }\end{array}$ & ASTER L1B, 22 Aug 2008 & 0.8 \\
\hline 2009 & Loss $(1.40)$ & Yes & $\begin{array}{c}\text { Partial open water and iceberg motion } \\
\text { along southern coast }\end{array}$ & ASTER L1B, 10 Jul 2009 & 0.9 \\
\hline 2010 & Loss $(0.38)$ & Yes & $\begin{array}{l}\text { Partial open water in Yelverton Bay and } \\
\text { southern coast of Petersen Bay }\end{array}$ & ASTER L1B, 19 Jul 2010 & 1.3 \\
\hline 2011 & Loss $(5.48)$ & Yes & $\begin{array}{l}\text { Visible open water at front and along } \\
\text { southern coast of Petersen Bay }\end{array}$ & MODIS Terra, 1 Aug 2011 & 2.8 \\
\hline 2012 & Loss (5.49) & Yes & $\begin{array}{l}\text { Visible open water at front and along } \\
\text { southern coast of Petersen Bay }\end{array}$ & ASTER L1B, 15 Jul 2012 & 2.3 \\
\hline
\end{tabular}

and open-water conditions at the front of the ice shelf and/or along the southern coast of Petersen Bay. In years when no large-scale calving was observed, summer air temperatures, while still above average, were relatively lower $\left(0.4-0.6^{\circ} \mathrm{C}\right.$ above 1948-2012 summer mean) and satellite imagery showed no evidence of open water (Table 5). Open water and particularly high summer air temperatures have become acute conditions that, when combined with chronic weakening of the ice shelf (i.e. thinning), facilitate ideal conditions for promoting ice-shelf break-up. Based on our remote-sensing and climate observations, we propose that three main factors have contributed to the break-up of the Petersen ice shelf:

\section{Factor 1: loss of MLSI/fast ice and open-water conditions}

This factor was apparent during all major recent calving events, with the effects of low sea-ice extent first apparent when 55-60-year-old MLSI drifted out from Yelverton Bay in August 2005 (Copland and others, 2007; Pope and others, 2012). The MLSI had provided a semi-permanent barrier protecting the margin of the ice shelf from the effects of waves, while providing back-pressure that likely held the ice shelf in place (Tsai and McNamara, 2011). Pan-Arctic sea-ice extent also experienced a record low in 2005 , at $21 \%$ below the 1979-2000 average ( $7 \%$ below the previous record low in 2002) (Serreze and others, 2007). The other major ice-shelf calving events, in 2008, 2011 and 2012, also occurred during years of low Arctic sea-ice extent (Wang and Overland, 2009; NSIDC, 2011; Zhang and others, 2013). In the low pan-Arctic sea-ice years there was extensive open water in the vicinity of the Petersen ice shelf. For example, Moderate Resolution Imaging Spectroradiometer (MODIS) imagery from August 2011 shows open-water conditions along the northern coast of Ellesmere Island, thus exposing the Petersen ice shelf to the effects of wave action. MODIS imagery from July and August 2012 also revealed open-water conditions along northern Ellesmere Island, while RADARSAT-2 imagery from 24 August 2012 showed open water surrounding the ice-shelf in Petersen Bay.

Factor 2: record high mean summer air temperatures This factor was apparent in the 2005, 2011 and 2012 calving events, when summer air temperatures were all $\geq 1.7^{\circ} \mathrm{C}$ above the long-term (1948-2012) summer mean. Although the break-up and calving events in 2008 did not occur during a record warm summer, air temperatures were still $0.8^{\circ} \mathrm{C}$ above the long-term average. However, it is also likely that sea-ice changes played a greater role in this particular year, as explained above.

Factor 3: pre-existing fractures and ice-shelf thinning Evidence for the weakening of the ice-shelf structure is provided by negative mass-balance conditions, and fracturing along areas such as troughs where GPR and ice-coring measurements indicate that the ice thickness is as little as $\sim 1 \mathrm{~m}$. The calving events in 2005 and 2008 occurred along pre-existing fractures that allowed the ice shelf to break apart in the absence of back-pressure from MLSI and pack ice (Fig. 6). In 2012 and 2013 the deterioration continued along the ice-shelf margins, where the ice was thinnest $(<20 \mathrm{~m})$ and most fractured (Fig. 2). Ice islands observed along the southern coast of the Petersen ice shelf in May 2011 and 2012 appear to be ridges that had broken away from the ice shelf along intervening troughs.

\subsection{Ice-shelf mass balance}

This study provides the first thickness measurements of the Petersen ice shelf. These indicate the importance of glacial input to the structure of the ice shelf, and likely its persistence (despite large recent losses) compared to the recent complete collapse of many surrounding ice shelves 
without current glacier inputs (e.g. Ayles, Markham). The thinnest regions $(<20 \mathrm{~m})$ of the Petersen ice shelf are along its seaward edge and particularly along its southern margin adjacent to the former epishelf lake region. Similar patterns were observed at the rear of the Milne Ice Shelf adjacent to the Milne Fiord epishelf lake (Mortimer and others, 2012). Based on the observed area changes, it is this southern margin that is currently deteriorating the most, and, according to the definition provided in Section 1, this region is now becoming too thin to meet the formal classification of an ice shelf, in spite of its relict ice-shelf surface morphology.

The Petersen ice shelf has experienced significant losses in extent since 2005, with a loss of $29.82 \mathrm{~km}^{2}$ between 2005 and 2012 ( $~ 61 \%$ of the June 2005 area). While the ice shelf continues to receive mass from two tributary glaciers, at an ice thickness equivalent of $1.19-5.65 \mathrm{Mta}^{-1}$, these inputs are far less than the mean surface ablation of $28.45 \mathrm{Mta}^{-1}$ $\left(1.15 \mathrm{~m}\right.$ w.e. $\left.\mathrm{a}^{-1}\right)$ measured in $2011 / 12$. Compared to previous studies of surface mass balance at the Milne and Ward Hunt ice shelves, the rate of surface lowering at the Petersen ice shelf is relatively high. From 1989 to 2003 Braun and others (2004) calculated surface ablation of $0.07 \mathrm{~m} \mathrm{w.e.}^{-1}$ for the Ward Hunt Ice Shelf, while Mortimer and others (2012) measured a mean surface ablation of $0.26 \mathrm{~m}$ w.e. $\mathrm{a}^{-1}$ for the Milne Ice Shelf (1981-2008/09).

While there is a possibility that basal freeze-on could be occurring below the ice shelf, it is unlikely, due to the very thin ice observed at certain spots across the ice shelf, particularly in troughs and along the ice-shelf margin $(<\sim 1 \mathrm{~m})$. Furthermore, the drainage of the epishelf lake in Petersen Bay (White, 2012) now prevents the possibility of basal accumulation via freshwater underflow as was described for the Ward Hunt Ice Shelf (Jeffries, 1992). If the mean surface ablation rate $\left(1.27 \mathrm{~m} \mathrm{a}^{-1}\right)$ is extrapolated across the entire ice-shelf area $\left(24.8 \mathrm{~km}^{2}\right.$ in February 2012) (yielding a loss of $28.45 \mathrm{Mt} \mathrm{a}^{-1}$ ) and combined with the calculated inputs from Glacier $1\left(1.65-3.09 \mathrm{Mta}^{-1}\right.$, assuming an ice thickness of $75 \mathrm{~m})$ and Glacier $2\left(0.08-1.52 \mathrm{Mta}^{-1}\right)$, this equates to a mass loss of 23.84-26.72 $\mathrm{Mta}^{-1}$. Assuming this rate remains constant over time, and neglecting any losses from calving, the ice shelf will no longer exist by the year 2041-44. This estimate is in line with the prediction by Hattersley-Smith and others (1955) that the northern Ellesmere ice shelves would be completely lost by the 2030s, based on ablation measurements from 1953 to 1954. However, the Petersen ice shelf is likely to break up long before this based on calving events observed over the past decade.

\section{CONCLUSION}

It is clear that large-scale reductions of the Petersen ice shelf have occurred over the past decade. Analysis of historical aerial photography and satellite imagery revealed general stability from 1959 to June 2005, followed by a series of calving events in summers 2005, 2008, 2011 and 2012. The events of 2005 were fundamental in a series of changes to Petersen Bay; long-term climate warming and the loss of the protective MLSI in Yelverton Bay likely led to calving at the front of the Petersen ice shelf $\left(8.07 \mathrm{~km}^{2}\right)$. Similar causal factors have been implicated in the recent losses of other nearby ice shelves, such as the Ayles in August 2005 (Copland and others, 2007).
The Petersen ice shelf is a relic of the greater Ellesmere ice shelf that developed under colder conditions in the past, which are necessary for ice growth and stability. While the precise relationship between climate and Arctic ice-shelf stability requires further investigation, it is apparent that the ice shelves are breaking up and calving in response to rising air temperatures $\left(+0.5^{\circ} \mathrm{C} \text { (decade }\right)^{-1}$ along the northern coast of Ellesmere Island between 1948 and 2012), the presence of new open-water regions along their fronts, and structural weakening via thinning and fracture development. Based on these past and present observations it is unlikely that the Petersen ice shelf, along with similar ice shelves on northern Ellesmere Island (Copland, 2009) and elsewhere in the Arctic (Williams and Dowdeswell, 2001; Dowdeswell, in press), will persist long into the future.

\section{ACKNOWLEDGEMENTS}

We thank the Canada Foundation for Innovation, the Ontario Research Fund, the Natural Sciences and Engineering Research Council of Canada, the Garfield Weston Foundation, the Royal Canadian Geographic Society, the Polar Continental Shelf Program, the Northern Scientific Training Program, ArcticNet, Carleton University and the University of Ottawa for financial and logistical support. We also thank Andrew Hamilton (University of British Columbia) and Miriam Richer-McCallum (Carleton University) for assistance in the field. NCEP Reanalysis data were provided by NOAA/ Office of Oceanic and Atmospheric Research (OAR)/Earth and Space Research Laboratory (ESRL) Physical Sciences Division (PSD), Boulder, CO. RADARSAT-1 data were provided by the Alaska Satellite Facility (ASF). RADARSAT-2 data were provided by the SOAR-E program of the Canadian Space Agency. RADARSAT is an official mark of the Canadian Space Agency. We are grateful for comments from two anonymous reviewers which greatly improved the text.

\section{REFERENCES}

Antoniades D, Francus P, Pienitz R, St-Onge G and Vincent WF (2011) Holocene dynamics of the Arctic's largest ice shelf. Proc. Natl Acad. Sci. USA (PNAS), 108(47), 18899-18904 (doi: 10.1073/pnas.1106378108)

ArcGIS (2009) ArcGIS Spatial Analyst: IDW. ArcGIS Desktop Help Bogorodsky VV, Bentley CR and Gudmandsen PE (1985) Radioglaciology. D. Reidel, Dordrecht

Braun C, Hardy DR, Bradley RS and Sahanatien V (2004) Surface mass balance of the Ward Hunt Ice Rise and Ward Hunt Ice Shelf, Ellesmere Island, Nunavut, Canada. J. Geophys. Res., 109(D22), D22110 (doi: 1029/2004JD004560)

Canadian Ice Service (CIS) (2005) Manual of Standard Procedures for Observing and Reporting Ice Conditions (MANICE), revised 9th edn. Meteorological Service of Canada, Environment Canada, Ottawa, Ont.

Copland L (2009) Review of recent changes in Canadian ice shelves. (Environment Canada contract KM149-08-2113) University of Ottawa, Ottawa, Ont.

Copland L, Mueller DR and Weir L (2007) Rapid loss of the Ayles Ice Shelf, Ellesmere Island, Canada. Geophys. Res. Lett., 34(21), L21501 (doi: 10.1029/2007GL031809)

Dowdeswell JA (in press) Eurasian Arctic ice shelves and tidewater glacier margins. In Copland L and Mueller DR eds. Arctic ice shelves and ice islands. Springer, Dordrecht

Dowdeswell JA and Jeffries MO (in press) Arctic ice shelves and ice islands: an introduction. In Copland $\mathrm{L}$ and Mueller DR eds. Arctic ice shelves and ice islands. Springer, Dordrecht 
England JH, Lakeman TR, Lemmen DS, Bednarski JM, Stewart TG and Evans DJA (2008) A millennial-scale record of Arctic Ocean sea ice variability and the demise of the Ellesmere Island ice shelves. Geophys. Res. Lett., 36(19), L19502 (doi: 10.1029/ 2008GL034470)

Hattersley-Smith G (1957) The rolls on the Ellesmere ice shelf. Arctic, 10(1), 32-44

Hattersley-Smith G, Crary, AP and Christie, RL (1955) Northern Ellesmere Island, 1953 and 1954. Arctic, 8(1), 3-36

Hattersley-Smith G, Fuzesy A and Evans S (1969) Glacier depths in northern Ellesmere Island: airborne radio echo sounding in 1966. (Operation Tanquary Report Geophysics Hazen 36) Defence Research Board, Department of National Defence, Ottawa, Ont.

Jeffries M (1982) The Ward Hunt Ice Shelf, spring 1982. Arctic, 35(4), 542-544

Jeffries MO (1987) The growth, structure and disintegration of Arctic ice shelves. Polar Rec., 23(147), 631-649 (doi: 10.1017/ S0032247400008342)

Jeffries MO (1992) Arctic ice shelves and ice islands: origin, growth and disintegration, physical characteristics, structural-stratigraphic variability, and dynamics. Rev. Geophys., 30(3), 245-267

Jeffries MO and Serson H (1983) Recent changes at the front of Ward Hunt Ice Shelf, Ellesmere Island, N.W.T. Arctic, 36(3), 289-290

Jeffries MO, Sackinger WM, Krouse HR and Serson HV (1988) Water circulation and ice accretion beneath Ward Hunt Ice Shelf (northern Ellesmere Island, Canada), deduced from salinity and isotope analysis of ice cores. Ann. Glaciol., 10, 68-72

Kalnay E and 21 others (1996) The NCEP/NCAR 40-year reanalysis project. Bull. Am. Meteorol. Soc., 77(3), 437-471 (doi: 10.1175/ 1520-0477(1996)077<0437:TNYRP >2.0.CO;2)

Kealey C, Mueller D and Copland L (2011) Canadian ice shelves breaking up at high speed. 27 September http://newsroom. carleton.ca/2011/09/27/canadian-ice-shelves-breaking-up-athigh-speed

Koenig LS, Greenaway KR, Dunbar M and Hattersley-Smith G (1952) Arctic ice islands. Arctic, 5(2), 67-103

Lesins G, Duck TJ and Drummond JR (2010) Climate trends at Eureka in the Canadian High Arctic. Atmos.-Ocean, 48(2), 59-80 (doi: 10.3137/AO1103.2010)

Lyons JB, Savin SM and Tamburi AJ (1971) Basement ice, Ward Hunt Ice Shelf, Ellesmere Island, Canada. J. Glaciol., 10(58), 93-100

Mortimer CA, Copland L and Mueller DR (2012) Volume and area changes of the Milne Ice Shelf, Ellesmere Island, Nunavut, Canada, since 1950. J. Geophys. Res., 117(F4), F04011 (doi: 10.1029/2011JF002074)

Mueller DR, Vincent WF and Jeffries MO (2003) Break-up of the largest Arctic ice shelf and associated loss of an epishelf lake. Geophys. Res. Lett., 30(20), 2031 (doi: 10.1029/2003GL017931)

Mueller DR, Vincent WF and Jeffries MO (2006) Environmental gradients, fragmented habitats, and microbiota of a northern ice shelf cryoecosystem, Ellesmere Island, Canada. Arct. Antarct. Alp. Res., 38(4), 593-607 (doi: 10.1657/1523-0430 (2006)38[593:EGFHAM]2.0.CO;2)

Mueller DR, Copland L, Hamilton A and Stern D (2008) Examining Arctic ice shelves prior to the 2008 breakup. Eos, 89(49), 502-503 (doi: 10.1029/2008EO490002)

Narod BB, Clarke GKC and Prager BT (1988) Airborne UHF radar sounding of glaciers and ice shelves, northern Ellesmere Island, Arctic Canada. Can. J. Earth Sci., 25(1), 95-105

National Snow and Ice Data Center (NSIDC) (2011) Arctic sea ice continues decline, reaches second-lowest level. NSIDC Notes, 77, 1 and 6 http://nsidc.org/pubs/notes/77/Notes_77_web.pdf

Paterson WSB (1994) The physics of glaciers, 3rd edn. Elsevier, Oxford

Pope S, Copland L and Mueller D (2012) Loss of multiyear landfast sea ice from Yelverton Bay, Ellesmere Island, Nunavut, Canada. Arct. Antarct. Alp. Res., 44(2), 210-221 (doi: 10.1657/19384246-44.2.210)

Prager BT (1983) Digital signal processing of UHF radio echo sounding data from northern Ellesmere Island. (MSc thesis, University of British Columbia)

Sensors \& Software (2003) EKKO_View Enhanced \& EKKO_View Deluxe user's guide. Sensors \& Software Inc., Mississauga, Ont.

Serreze MC, Holland MM and Stroeve J (2007) Perspectives on the Arctic's shrinking sea-ice cover. Science, 315(5818), 1533-1536 (doi: 10.1126/science.1139426)

Short NH and Gray AL (2005) Glacier dynamics in the Canadian High Arctic from RADARSAT-1 speckle tracking. Can. J. Remote Sens., 31(3), 225-239 (doi: 10.5589/m05-010)

Tsai VC and McNamara DE (2011) Quantifying the influence of sea ice on ocean microseism using observations from the Bering Sea, Alaska. Geophys. Res. Lett., 38(22), L22502 (doi: 10.1029/ 2011GL049791)

Van Wychen W, Copland L, Gray L, Burgess D, Danielson B and Sharp M (2012) Spatial and temporal variation of ice motion and ice flux from Devon Ice Cap, Nunavut, Canada. J. Glaciol., 58(210), 657-664 (doi: 10.3189/2012JoG11J164)

Vincent WF, Gibson JAE and Jeffries MO (2001) Ice-shelf collapse, climate change, and habitat loss in the Canadian high Arctic. Polar Rec., 37(201), 133-142 (doi: 10.1017/ S0032247400026954)

Wang M and Overland JE (2009) A sea-ice free summer Arctic within 30 years? Geophys. Res. Lett., 36(7), L07502 (doi: 110.1029/2009GL037820)

White A (2012) Dynamics and historical changes of the Petersen Ice Shelf and epishelf lake, Nunavut, Canada, since 1959. (MSc thesis, University of Ottawa)

Williams M and Dowdeswell JA (2001) Historical fluctuations of the Matusevich Ice Shelf, Severnaya Zemlya, Russian High Arctic. Arct. Antarct. Alp. Res., 33(2), 211-222

Zhang J, Lindsay R, Schweiger A and Steele M (2013) The impact of an intense summer cyclone on 2012 Arctic sea ice retreat. Geophys. Res. Lett., 40(4), 720-726 (doi: 10.1002/grl.50190) 